\title{
Klinik Enterobacterales İzolatlarında Plazmit Aracılı mor Kolistin Direnç Geninin Araştırılması
}

\section{Investigation of Plasmid Mediated mcr Colistin Resistance Gene in Clinical Enterobacterales Isolates}

\author{
Esra ÖZKAYA ${ }^{1}(I D)$, Celal Kurtuluş BURUK¹(ID), illknur $\operatorname{TOSUN}^{1}\left(\right.$ ID), Bayram $\operatorname{TORAMAN}^{2}($ ID), \\ Neşe KAKLIKKAYA ${ }^{1}(I D)$, Faruk AYDIN ${ }^{1}(I D)$ \\ ${ }^{1}$ Karadeniz Teknik Üniversitesi Tıp Fakültesi, Tıbbi Mikrobiyoloji Anabilim Dalı, Trabzon. \\ ${ }^{1}$ Karadeniz Technical University Faculty of Medicine, Department of Medical Microbiology, Trabzon, Turkey. \\ ${ }^{2}$ Karadeniz Teknik Üniversitesi Tıp Fakültesi, Tıbbi Biyoloji Anabilim Dalı, Trabzon. \\ ${ }^{2}$ Karadeniz Technical University Faculty of Medicine, Department of Medical Biology, Trabzon, Turkey.
}

* Bu çalışma, 5. Ulusal Klinik Mikrobiyoloji Kongresi (28 Ekim-01 Kasım 2019, İzmir, Türkiye)’nde sözlü sunum olarak
sunulmuştur.

Makale Atıfı: Özkaya E, Buruk CK, Tosun i, Toraman B, Kaklıkkaya N, Aydın F. Klinik Enterobacterales izolatlarında plazmit aracılı mor kolistin direnç geninin araştırılması. Mikrobiyol Bul 2020;54(2):191-202.

\section{ÖZ}

Çoklu ilaca dirençli bakterilerin neden olduğu enfeksiyonlarda karbapenemler, karbapeneme dirençli olanlarda ise kolistin (polimiksin E) son çare olarak kullanılmaktadır. Gram-negatif bakterilerin sitoplazmik membranının geçirgenliğini bozarak hücre ölümüne neden olan kolistinin tüm dünyada kullanımının artışı direnç sorununu gündeme getirmiştir. Aktarılabilir kolistin direnci enzimi olan $m c r$, lipid A'ya fosfoetanolamin eklenip lipopolisakkaritleri modifiye ederek polimiksin direncine yol açan bir fosfoetanolamin transferazdır. Bu çalışmada kolistine dirençli Enterobacterales izolatlarında en yaygın görülen plazmit aracılı bazı kolistin ve karbapenemaz direnç genlerinin araştıııması amaçlanmıştır. Çalışmada Karadeniz Teknik Üniversitesi Tıp Fakültesi Farabi Hastanesi Tıbbi Mikrobiyoloji Laboratuvarında Ekim 2016-Eylül 2018 tarihleri arasında klinik birimlerde tedavi gören hastaların numunelerinde tespit edilen Enterobacterales izolatları kullanılmıştır. İzolatlar klasik yöntemlere ilaveten MALDI-TOF-MS (Bruker Daltonics, Almanya) ile tür düzeyinde tanımlanmıştır. Enterobacterales izolatlarının antibiyotik duyarlılıkları Phoenix (Becton Dickinson, ABD) otomatize mikrobiyoloji sistemi ile çalışılmıştır ve "European Committee on Antimicrobial Susceptibility Testing (EUCAST)" önerilerine göre değerlendirilmiştir. Kolistine dirençli bulunan izolatlarda ve duyarlı saptanan ancak kolistin duyarlılık test sonucu hasta raporuna eklenmesi gereken izolatlarda kolistin duyarlılık testleri EUCAST standartlarına uygun olarak sıvı mikrodilüsyon yöntemiyle tekrarlanmıştır. Kolistine dirençli Enterobacterales izolatlarında EUCAST önerileri doğrultusunda genişlemiş spektrumlu beta-laktamaz (GSBL), AmpC beta-laktamaz ve karbapenemaz varlığı fenotipik yöntemlerle araştııımışıı. Ayrıca, polimeraz zincir reaksiyonu (PCR) yöntemiyle $m c r-1-5, b l a_{\mathrm{OXA}-48^{\prime}} b l a_{\mathrm{KPC}^{\prime}} b l a_{\mathrm{NDM}^{\prime}} b l a_{\mathrm{VIM}^{\prime}} b l a_{\mathrm{IMP}}$ direnç genleri araştırılmış, ardından amplifiye edilen ürünlerin nükleotit dizi analizleri yapılmıştı. Çalışmamızda, farklı klinik birimlerde tedavi gören 7535 hastaya ait 14657 Enterobacterales izolatı retrospektif olarak irdelendiğinde en sık Escherichia coli \%61.2 ( $n=8968)$, Klebsiella pneumoniae \%22.7 ( $n=3334)$ ve Enterobacter cloacae \%6.9 $(n=1005)$ olduğu görülmüştür. Karbapenem direnci toplamda 894 izolatta tespit edilmiş olup; Ekim 2016-Eylül 2017 
tarihleri arasında izole edilen 7135 izolatın \%5.8 $(n=412)$ 'i, Ekim 2017-Eylül 2018 tarihleri arasında izole edilen 7522 izolatın \%6.4 ( $\mathrm{n}=482)^{\prime}$ 'ü dirençli bulunmuştur. Tüm izolatlar içinde kolistine dirençli bulunan izolatlar Ekim 2016-Eylül 2017 tarihleri arasında 65 (\%0.9) iken, Ekim 2017-Eylül 2018 tarihleri arasında 97 (\%1.3)'dir. Aynı hastaya ait farklı örneklerdeki aynı etken üremelerinde sadece ilk izolatlar çalışmaya dahil edilerek kolistine dirençli 46 izolat seçilmiştir. Stok kültürden üretilemeyen 6 izolat çalışma materyalinden çıkarıımıştır. Çalışmaya dahil edilen kolistine dirençli 40 Enterobacterales izolatının 13 (\%32.5)'ü 2017, 27 (\%67.5)'si 2018 yılında izole edilmiştir. Bu izolatların 22'sinde GSBL, 6'sında AmpC beta-laktamaz, 15'inde karbapenem direnci fenotipik yöntemlerle tespit edilmiştir. Bu işlemlerin ardından PCR yöntemiyle 2 izolatta $m c r-1,2$ izolatta $b l a_{\mathrm{OXA}-48}, 1$ izolatta $b l a_{\mathrm{VIM}^{\prime}} 1$ izolatta $b l a_{\mathrm{KPC}}$ ve $b l a_{\mathrm{OXA}-48}$ birlikteliği, 5 izolatta bla $\mathrm{NDM}_{\text {ve }}$ blaOXA-48 birlikteliği tespit edilmiştir. $m c r-1$ saptanan izolatlarda nükleotit dizi analizi ile doğrulama yapıımıştır. Tespit edilen $m c r-1$ genleri hastanemizde tedavi gören 65 yaş üstü 2 kadın hastanın idrar kültürü örneklerinde üreyen E.coli izolatlarında bulunmuştur. Bu hastalardan 1 'inde test edilen antibiyotikler arasında sadece ampisiline direnç gözlenmiş, diğerinde ise ampisilin, amoksisilin-klavulonik asit ve siprofloksasine direnç belirlenmiştir. Sonuç olarak, yayınımız literatürde ulaşabildiğimiz kadarıyla ülkemizde klinik örneklerde $m c r-$ 1 geni varlığını gösteren ve DNA dizi analizi ile doğrulanmış ilk çalışmadır. Çoklu ilaç direnci görülmeyen izolatlarda mor geninin saptanmış olması tıbbi mikrobiyoloji laboratuvarlarında kolistin duyarlılık testi çalışıımasının önemini bir kez daha gözler önüne sermektedir. Ayrıca çalışmamızda farklı direnç genlerini bir arada içeren izolatların saptanmış olması, karbapenem ve kolistin direncinin yayılımının beklenenden daha hızlı olabileceğini bir kez daha hatırlatmıştır.

Anahtar kelimeler: Enterobacterales; kolistin direnci; karbapenem direnci; mcr-1 geni.

\section{ABSTRACT}

Carbapenems are used in the treatment of infections caused by multidrug-resistant bacteria and colistin (polymyxin E) is used as the last choice of antimicrobial agent in those resistant to carbapenems. The worldwide and increased use of colistin, which causes cell death by disrupting the permeability of the cytoplasmic membrane of gram-negative bacteria, raised the problem of resistance. The transferable colistin resistance enzyme $m c r$, is a phosphoethanolamine transferase that adds phosphoethanolamine to lipid A and modifies lipopolysaccharides, leading to polymyxin resistance. The aim of this study was to investigate some of the most prevalent plasmid mediated colistin and carbapenemase resistance genes in colistin resistant Enterobacterales isolates. Enterobacterales isolates which were isolated in the samples of patients treated in the clinical units between October 2016 and September 2018 in the Karadeniz Technical University Faculty of Medicine Farabi Hospital Medical Microbiology Laboratory were included in the study. In addition to conventional methods, isolates were identified to the species level by MALDI-TOF MS (Bruker Daltonics, Germany). The antibiotic susceptibilities of Enterobacterales isolates were studied by an automated microbiology system (Phoenix, Becton Dickinson, USA) and evaluated according to European Committee on Antimicrobial Susceptibility Testing (EUCAST) criteria. In isolates that are resistant to colistin, and the isolates that are found to be sensitive but should be included in the patient report of the colistin susceptibility test, colistin susceptibility tests were repeated with liquid microdilution method in accordance with EUCAST standards. The presence of extended spectrum beta-lactamase (ESBL), AmpC beta-lactamase and carbapenemase were determined by phenotypic methods according to EUCAST recommendations in colistin resistant Enterobacterales isolates. Furthermore, resistance genes of $m c r-1-5, b / a_{\mathrm{OXA}-48^{\prime}} b / a_{\mathrm{KPC}}$ $b / a_{\mathrm{NDM}^{\prime}} b l a_{\mathrm{VIM}^{\prime}} b / a_{\mathrm{IMP}}$ were detected by polymerase chain reaction (PCR) method, followed by nucleotide sequence analysis of the amplified products. In our study, 14657 Enterobacterales isolates belonging to 7535 patients treated in different clinical units were examined retrospectively. Escherichia coli $61.2 \%(n=$ 8968), Klebsiella pneumoniae $22.7 \%(n=3334)$ and Enterobacter cloacae $6.9 \%(n=1005)$ were the most prevalent isolates. Carbapenem resistance was detected in 894 isolates, and $5.8 \%(n=412)$ of 7135 isolates isolated between October 2016 and September 2017; 6.4\% ( $n=482)$ of 7522 isolates between October 2017 and September 2018 were found to be resistant. Considering all isolates, colistin resistant isolates were 65 (0.9\%) between October 2016 and September 2017 and 97 (1.3\%) between October 2017 and September 2018. By including only the first isolates in the study for the same agent growths in different samples of the same patient, 46 colistin resistant isolates were selected. Six isolates which could not be cultivated from stock cultures were excluded from the study material. Thirteen (32.5\%) of the 40 colistin resistant Enterobacterales isolates were isolated in 2017 and 27 (67.5\%) were isolated in 2018. ESBL was 
detected in 22, AmpC beta-lactamase was detected in 6, carbapenem resistance was detected in 15 of them by phenotypic methods. As a result of PCR analysis, $m c r-1$ gene detected in 2 isolates, $b l a_{\text {OXA-48 }}$ in 2 isolates, $b / a_{\mathrm{VIM}}$ in 1 isolate, $b / a_{\mathrm{KPC}}$ and $b / a_{\mathrm{OXA}-48}$ in 1 isolate, $b / a_{\mathrm{NDM}}$ and $b / a_{\mathrm{OXA}-48}$ in 5 isolates. These results were confirmed by sequencing of the PCR products. The $m c r-1$ genes were found in E.coli isolates grown in urine culture samples of 2 women over 65 years of age treated in our hospital. Among the antibiotics tested, only ampicillin resistance was observed in 1 of the patients, whereas ampicillin, amoxicillin-clavulanate and ciprofloxacin resistance were detected in the other. In conclusion, as far as we can reach in the literature our publication is the first study showing the presence of $m c r-1$ gene in clinical samples in our country and confirmed by DNA sequence analysis. The detection of $\mathrm{mcr}$ gene in isolates without multidrug resistance showed once again the importance of colistin susceptibility testing in the laboratories. In addition, the presence of isolates containing more than one resistance genes in our study, suggests that the spread of carbapenem and colistin resistance may be faster than expected.

Keywords: Enterobacterales; resistance to colistin; resistance to carbapenems; mcr-1 gene.

\section{Giriş}

Karbapenemler ve kolistin günümüzde özellikle immün sistemi baskılanmış hastalardaki gram-negatif bakteri enfeksiyonlarında hayat kurtarıcıdır. Nitekim, genişlemiş spektrumlu beta-laktamaz (GSBL) üreten çoklu ilaca dirençli bakterilerin neden olduğu enfeksiyonlarda karbapenemler, karbapeneme de dirençli olanlarda ise kolistin (polimiksin E) son çare olarak kullanılmaktadır ${ }^{1,2}$. Gram-negatif bakterilerin sitoplazmik membranının geçirgenliğini bozarak hücre ölümüne neden olan kolistinin tüm dünyada kullanımının artışı direnç sorununu yanında getirmiştir ${ }^{1,3}$. Çin'de Lui ve arkadaşları, 2015 yılında Enterobacterales izolatlarında plazmit aracılı $m c r-1$ kolistin direnç geninin varlığını gösterene kadar, kolistin direncinin yalnızca kromozomal mutasyonlardan kaynaklandığı bilinmekteydi ${ }^{1,4}$. Mcr-1 enzimi, lipid A'ya fosfoetanolamin eklenip lipopolisakkaritleri modifiye ederek polimiksin direncine yol açan bir fosfoetanolamin transferazdır ${ }^{3}$. mcr-1'in tespitinden kısa bir süre sonra diğer Mcr homologlarının ( $m c r-2-9)$ bildirimleri yapılmıştır ve direnç genlerinin izolatlar arasında transfer olabileceği gösterilmiştir ${ }^{5,6}$.

Çalışmamızda Karadeniz Teknik Üniversitesi Tıp Fakültesi Farabi Hastanesi Tıbbi Mikrobiyoloji Laboratuvarında, Ekim 2016-Eylül 2018 tarihleri arasında çeşitli klinik örneklerden izole edilen kolistine dirençli Enterobacterales ailesi üyesi izolatlarda en yaygın görülen plazmit aracılı bazı kolistin ve karbapenemaz direnç genlerinin araştırılması amaçlanmıştır.

\section{GEREÇ ve YÖNTEM}

Bu çalışma, Karadeniz Teknik Üniversitesi Tıp Fakültesi Bilimsel Araştırmalar Etik Kurulu onayı ile gerçekleştirildi (Tarih: 31.12.2018 ve Karar no: 24237859-10).

\section{Bakteri İzolatları}

Bu çalışmada, Ekim 2016-Eylül 2018 tarihleri arasında laboratuvarımızda klinik örneklerden izole edilen ve uygun şartlarda saklanan Enterobacterales izolatları kullanıldı.

\section{Enterobacterales İzolatlarının Tanımlanması}

Laboratuvarımıza gönderilen klinik örnekler, \%5 koyun kanlı agar (BD, Becton Dickinson, $A B D$ ), EMB agar (Oxoid, İngiltere) ve çikolata agar (Becton Dickinson, ABD) besiyer- 
lerine ekilerek $24-48$ saat $35-37^{\circ} \mathrm{C}^{\prime}$ de aerobik ortamda inkübe edildi ve üreyen koloniler değerlendirmeye alındı. Mikroskobik incelemede gram-negatif basil görünümünde olan koloniler, klasik yöntemlere ilaveten MALDI Biotyper (Bruker Daltonics, Almanya) ile üretici firma önerileri doğrultusunda tür düzeyinde tanımlandı.

\section{Antimikrobiyal Duyarlılık Testleri ve Minimum İnhibitör Konsantrasyonu (MiK) Tayini}

Enterobacterales olarak tanımlanan izolatların antibiyotik duyarlılıkları Phoenix (Becton Dickinson, $\mathrm{ABD}$ ) otomatize mikrobiyoloji sistemi ile çalışıldı ve "European Committee on Antimicrobial Susceptibility Testing (EUCAST)" kriterlerine göre değerlendirildi ${ }^{7}$. Uygunsuz direnç profillerindeki testler disk difüzyon, antibiyotik gradiyent ve/veya sıvı mikrodilüsyon testleri ile tekrarlandı.

Çalışma süresince tüm Enterobacterales izolatlarında otomatize sistem ile kolistin direnci tarandı. Bu yöntemle dirençli bulunan izolatlarda ve duyarlı saptanan ancak kolistin duyarlılık test sonucu hasta raporuna eklenmesi gereken izolatlarda kolistin duyarlılık testleri EUCAST standartlarına uygun olarak sıvı mikrodilüsyon yöntemi ile tekrarlandı ${ }^{7}$. Kalite kontrol için Escherichia coli ATCC 25922 ve E.coli NCTC 13846 suşları kullanıldı.

\section{GSBL ve AmpC Beta-Laktamaz Saptanması}

EUCAST önerileri doğrultusunda GSBL çift disk sinerji; AmpC beta-laktamaz testi ise sefoksitin/sefoksitin-boronik asit diskleri kullanılarak kombine disk yöntemi ile çalışıldı. Bu testlerde kalite kontrol için E.coli ATCC 25922, Klebsiella pneumoniae ATCC 700603 ve K.pneumoniae ATCC 13883 suşları kullanıldı, ${ }^{8,9}$.

\section{Karbapenemazların Belirlenmesi}

Enterobacterales izolatlarında karbapenemaz varlığı karbapenem inaktivasyon yöntemi (CIM) kullanılarak araştırıldı ${ }^{10}$. Bu incelemeler sırasında KPC pozitif olan K.pneumoniae ATCC BAA1705 ve KPC negatif olan K.pneumoniae BAA1706 kontrol suşları olarak kullanıldı.

Moleküler analizler uygulanıncaya kadar izolatlar \%15 gliserol (Merck, Almanya) içeren triptik soy buyyon besiyerinde (Fluka, 22092, ABD) $-80^{\circ} \mathrm{C}^{\prime}$ de saklandı ${ }^{11}$.

\section{İzolatların Yeniden Canlandırılması ve DNA İzolasyonu}

Çalışmaya dahil edilen seçilmiş izolatlar stoklardan çıkarılarak \%5 koyun kanlı agarda pasajlandı. Karbapenem ve kolistin duyarlıık testleri tekrarlandı. DNA izolasyonu için bir öze dolusu izolat, $500 \mu \mathrm{l}$ steril saf su içinde süspanse edildi. 2500 × g'de bir dakika santrifüj edilerek süpernatan uzaklaştırıldı. Aynı işlem iki kez daha tekrar edildikten sonra çökelti 500 $\mu$ steril Tris-EDTA (TE), pH= 8 tamponu içinde yeniden süspanse edildi. Çözelti kaynayan saf su içinde 10 dakika bekletildikten sonra 10.000 x g'de 5 dakika santrifüj edildi. Steril saf su ile 10 kat sulandırılan süpernatan alikotlanarak kullanılıncaya kadar dondurucuda stoklandı.

\section{Polimeraz Zincir Reaksiyonu (PCR)}

Fenotipik yöntemlerle kolistin direnci saptanan izolatlarda mcr-1-5, karbapenem direnci saptanan izolatlarda ise bla $a_{\mathrm{OXA}-48^{\prime}} b l a_{\mathrm{KPC}^{\prime}} b l a_{\mathrm{NDM}^{\prime}} b / a_{\mathrm{VIM}^{\prime}} b / a_{\mathrm{IMP}}$ gen varlığı araştırıldı. Bu 
işlem için toplam $25 \mu$ l'lik hacmin içinde; $5 \mu$ tampon (Promega Madison, WI, ABD), 1 U DNA polimeraz (Promega, Madison, WI, ABD), 0.2 mM dNTP karışımı (Ampliqon, Danimarka), $0.2 \mu \mathrm{M}$ primer (Oligomer, Ankara), $1.5 \mathrm{mM} \mathrm{MgCl}_{2}$ ve $2 \mu$ l kalıp DNA olacak şekilde PCR karışımı hazırlandı. Kullanılan primerler Tablo I'de sunulmuştur. Amplifikasyon koşulları; $94^{\circ} \mathrm{C}^{\prime}$ de 5 dakika başlangıç denatürasyonu sonrası, her döngü için $94^{\circ} \mathrm{C}^{\prime}$ de 30 sn denatürasyon, $58^{\circ} \mathrm{C}^{\prime}$ de 90 sn primer birleşmesi, $72^{\circ} \mathrm{C}^{\prime}$ de 60 sn polimerizasyon aşamalarını içeren 25 döngü ve sonrasında $72^{\circ} \mathrm{C}^{\prime}$ de 10 dakika son uzama süresi olarak düzenlendi. Cihazda (Applied Biosystems ${ }^{\circledR}$ GeneAmp ${ }^{\circledR}$ PCR System 9700, ABD) gerçekleştirilen amplifikasyon işleminin sonucu, $0.5 \mu \mathrm{g} / \mathrm{ml}$ etidyum bromür içeren $\% 1.5^{\prime}$ lik agaroz jele yüklenen ürünlerin 110 Volt'da elektroforezi sonrası UV transilüminatörde gözlendi.

\section{Nükleotit Dizi Analizi}

Agaroz jel elektroforezi sonucunda büyüklükleri uyumlu olan bant gözlenen PCR ürünleri temizlendikten sonra aynı PCR primerleri ile dizileme döngüsü (cycle sequencing) gerçekleştirildi (BigDye ${ }^{\mathrm{T} M}$ Terminator v3.1 Cycle Sequencing Kit, Waltham, MA, ABD). Dizileme işlemi ABI PRISM ${ }^{\circledR} 3100$ Genetic analizörde (Applied Biosystems, ABD) ger-

\begin{tabular}{|c|c|c|c|}
\hline Primer adı & Dizisi $\left(5^{\prime}-3^{\prime}\right)$ & $\begin{array}{l}\text { Amplikon büyüklüğğü } \\
\text { (bp) }\end{array}$ & Kaynak \\
\hline CLR F & F- CGG TCA GTC CGT TTG TTC & 309 & 1 \\
\hline CLR R & R- CTT GGT CGG TCT GTA GGG & & \\
\hline MCR2 IF & F- TGT TGC TTG TGC CGA TTG GA & 567 & 5 \\
\hline MCR2 IR & R- AGA TGG TAT TGT TGG TTG CTG & & \\
\hline mcr3_900bp_fw & F- AAA TAA AAA TTG TTC CGC TTA TG & 929 & 12 \\
\hline mcr3_900bp_rev & R- AAT GGA GAT CCC CGT TTT T & & \\
\hline mcr4_1100bp_fw & F- TCA CTT TCA TCA CTG СGT TG & 1116 & 12 \\
\hline mcr4_1100bp_rev & R- TTG GTC CAT GAC TAC CAA TG & & \\
\hline MCR5_fw & F- ATGCGGTTGTCTGCATTTATC & 1644 & 13 \\
\hline MCR5_rev & R- TCATTGTGGTTGTCCTITTCTG & & \\
\hline \multirow[t]{2}{*}{$b l a_{\mathrm{KPC}}$} & F- GATACCACGTTCCGTCTGG & 246 & 14 \\
\hline & R- GCAGGTTCCGGTTTTGTCTC & & \\
\hline \multirow[t]{2}{*}{$b / a_{\mathrm{OXA}-48}$} & F- TTGGTGGCATCGATTATCGG & 744 & 15 \\
\hline & R- GAGCACTTCTTTTGTGATGGC & & \\
\hline \multirow[t]{2}{*}{$b / a_{\mathrm{NDM}}$} & TCG ATC CCA ACG GTG ATA TT & 287 & 15 \\
\hline & TGG ATC AAG CAG GAG ATC AA & & \\
\hline \multirow[t]{2}{*}{$b l a_{\mathrm{VIM}}$} & AGT GGT GAG TAT CCG ACA G & 261 & 16 \\
\hline & ATG AAA GTG CGT GGA GAC & & \\
\hline \multirow[t]{2}{*}{$b / a_{\mathrm{IMP}}$} & CTA CCG CAG CAG AGT CTT TG & 587 & 16 \\
\hline & AAC CAG TTT TGC CTT ACC AT & & \\
\hline
\end{tabular}


çekleştirildi. Elde edilen dizilerin benzerliği "Basic Local Alignment Search Tool (BLAST)" kullanılarak araştırıldı.

\section{BULGULAR}

Çalışmamızda, farklı klinik birimlerde tedavi gören 7535 hastaya ait 14657 Enterobacterales izolatı retrospektif olarak irdelenmiş ve en sık E.coli \%61.2 ( $\mathrm{n}=8968)$, K.pneumoniae $\% 22.7$ ( $n=3334$ ) ve Enterobacter cloacae \%6.9 ( $n=1005)$ olduğu görülmüştür. Karbapenem direnci toplamda 894 izolatta tespit edilmiş ve Ekim 2016-Eylül 2017 tarihleri arasında izole edilen 7135 izolatın \%5.8 ( $n=412)^{\prime}$ i; Ekim 2017-Eylül 2018 tarihleri arasında izole edilen 7522 izolatın \%6.4 ( $n=482$ )'ü dirençli bulunmuştur. Tüm izolatlar içinde kolistine dirençli bulunan izolatlar Ekim 2016-Eylül 2017 tarihleri arasında 65 (\%0.9) iken, Ekim 2017-Eylül 2018 tarihleri arasında 97 (\%1.3) olarak tespit edilmiştir. Hastaların tekrarlayan üremelerinde sadece ilk örnekleri çalışmaya dahil edilerek kolistine dirençli 46 izolat seçilmiştir. Stok kültürden üretilemeyen 6 izolat çalışma materyalinden çıkarılmıştır. Çalışmaya dahil edilen kolistine dirençli 40 Enterobacterales izolatının 13 (\%32.5)'ü 2017, 27 (\%67.5)'si 2018 yılında izole edilmiştir.

Çalışma süresince tüm Enterobacterales izolatlarında otomatize sistem kolistin direnci taranmıştır. Bu yöntemle dirençli bulunan izolatlar ve duyarlı saptanan ancak kolistin duyarlıık test sonucu hasta raporuna eklenmesi gereken izolatların kolistin duyarlılık testi EUCAST standartlarına uygun olarak sıvı mikrodilüsyon yöntemi ile tekrarlanmıştır. Her iki çalışma arasında uyumsuzluk tespit edilmiştir. Tüm izolatlar içinde kolistine dirençli bulunan 40 izolat çalışmaya alınmıştır. Çalışmaya dahil edilen kolistine dirençli Enterobacterales izolatlarının kolistin MiK oranları Tablo II'de sunulmuştur.

Kolistine dirençli izolatların 26 (\%65.0)'sının hastane kaynaklı, 14 (\%35.0)'ünün toplum kaynaklı, bu izolatların da en sık (\%42.5) yoğun bakım ünitelerinden gelen örneklerden olduğu saptanmıştır.

Çalışmaya dahil edilen kolistine dirençli Enterobacterales izolatlarının 22'sinde GSBL, altısında AmpC beta-laktamaz, 15'inde karbapenem direnci varlığı fenotipik yöntemlerle tespit edilmiştir. Bu işlemlerin ardından uygulanan PCR analizinde 2 izolatta $m c r-1,2$ izolatta $b / a_{\mathrm{OXA}-48^{\prime}} 1$ izolatta $b / a_{\mathrm{VIM}^{\prime}} 1$ izolatta $b a_{\mathrm{KPC}}$ ve bla ${ }_{\mathrm{OXA}-48}$ birlikteliği, 5 izolatta

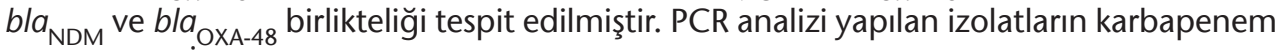
ve kolistin MiK değerleri, fenotipik ve genotipik test sonuçları Tablo III'te gösterilmiştir.

\begin{tabular}{|lccc|}
\hline \multicolumn{4}{l}{ Tablo II. Kolistine Dirençli Enterobacterales izolatlarının Kolistin MiK Oranları } \\
\hline Bakteri izolatları & MiK aralığı $(\mu \mathrm{g} / \mathrm{ml})$ & MiK $_{50}$ & Mik $_{90}$ \\
\hline Klebsiella pneumoniae $(\mathrm{n}=19)$ & $8->64$ & 64 & $>64$ \\
Escherichia coli $(\mathrm{n}=14)$ & $4-32$ & 16 & 32 \\
Klebsiella aerogenes $(\mathrm{n}=4)$ & $16->64$ & 32 & $>64$ \\
Enterobacter cloacae $(\mathrm{n}=3)$ & $64->64$ & $>64$ & $>64$ \\
\hline MiK: Minimum inhibitör konsantrasyonu. & & &
\end{tabular}




\begin{tabular}{|c|c|c|c|c|c|c|c|c|c|}
\hline $\begin{array}{l}\text { İzolat } \\
\text { no }\end{array}$ & Bakteri türü & $\begin{array}{c}\text { ERT } \\
(\mu \mathrm{g} / \mathrm{ml})\end{array}$ & $\begin{array}{c}\text { iMP } \\
(\mu \mathrm{g} / \mathrm{ml})\end{array}$ & $\begin{array}{c}\text { MEM } \\
(\mu \mathrm{g} / \mathrm{ml})\end{array}$ & $\begin{array}{c}\mathrm{CO} \\
(\mu \mathrm{g} / \mathrm{ml})\end{array}$ & GSBL & AMP-C & CIM & $\begin{array}{l}\text { Direnç } \\
\text { genleri }\end{array}$ \\
\hline TK-1 & K.pneumoniae & $>1$ & 4 & 4 & 64 & Pozitif & Negatif & Pozitif & $\underset{\text { bla }_{\mathrm{ODA}-48}}{+}$ \\
\hline TK-2 & E.cloacae & 1 & 2 & $\leq 0.125$ & 64 & Negatif & Pozitif & Negatif & - \\
\hline TK-3 & E.coli & $\leq 0.25$ & $\leq 0.25$ & $\leq 0.125$ & 32 & Negatif & Negatif & Negatif & - \\
\hline TK-4 & K.pneumoniae & $\leq 0.25$ & 1 & $\leq 0.125$ & 32 & Pozitif & Negatif & Negatif & - \\
\hline TK-5 & K.aerogenes & 0.5 & $\leq 0.25$ & $\leq 0.125$ & $>64$ & Negatif & Pozitif & Negatif & - \\
\hline TK-6 & E.coli & $\leq 0.25$ & $\leq 0.25$ & $\leq 0.125$ & 32 & Negatif & Negatif & Negatif & - \\
\hline TK-7 & E.coli & $\leq 0.25$ & $\leq 0.25$ & $\leq 0.125$ & 32 & Pozitif & Negatif & Negatif & - \\
\hline TK-8 & K.pneumoniae & $>1$ & 8 & 8 & $>64$ & Pozitif & Negatif & Pozitif & $\underset{\text { bla }_{\mathrm{NDM}}}{b l a_{\mathrm{OX}-48}}+$ \\
\hline TK-9 & E.cloacae & $\leq 0.25$ & 1 & $\leq 0.125$ & $>64$ & Negatif & Negatif & Pozitif & - \\
\hline TK-10 & K.pneumoniae & $>1$ & 8 & $>8$ & $>64$ & Pozitif & Negatif & Pozitif & $b / a_{\mathrm{OXA}-48}$ \\
\hline TK-11 & K.pneumoniae & $>1$ & 8 & $>8$ & 64 & Pozitif & Negatif & Pozitif & $\underset{\text { bla }_{\mathrm{NDM}}}{\text { bla }_{\mathrm{O}}}+$ \\
\hline TK-12 & K.aerogenes & $\leq 0.25$ & $\leq 0.25$ & $\leq 0.125$ & 16 & Negatif & Negatif & Pozitif & - \\
\hline TK-13 & E.coli & $\leq 0.25$ & 0.5 & $\leq 0.125$ & & Negatif & Negatif & Negatif & $m c r-1$ \\
\hline TK-14 & K.pneumoniae & $\leq 0.25$ & $\leq 0.25$ & $\leq 0.125$ & 16 & Pozitif & Negatif & Negatif & - \\
\hline TK-15 & K.pneumoniae & $>1$ & $>8$ & $>8$ & 8 & Negatif & Negatif & Pozitif & $b / a_{\text {OXA-48 }}$ \\
\hline TK-16 & E.coli & $\leq 0.25$ & $\leq 0.25$ & $\leq 0.125$ & 32 & Pozitif & Negatif & Negatif & - \\
\hline TK-17 & E.coli & $\leq 0.25$ & $\leq 0.25$ & $\leq 0.125$ & 32 & Negatif & Negatif & Negatif & - \\
\hline TK-18 & K.pneumoniae & $\leq 0.25$ & $\leq 0.25$ & $\leq 0.125$ & 64 & Pozitif & Negatif & Negatif & - \\
\hline TK-19 & E.coli & $\leq 0.25$ & $\leq 0.25$ & $\leq 0.125$ & 16 & Pozitif & Negatif & Negatif & - \\
\hline TK-20 & K.pneumoniae & 0.25 & $\leq 0.25$ & $\leq 0.125$ & 64 & Pozitif & Negatif & Negatif & - \\
\hline TK-21 & K.pneumoniae & $>1$ & $>8$ & $>8$ & 32 & Pozitif & Negatif & Pozitif & $\begin{array}{c}b l a_{\mathrm{OXA}-48} \\
\text { bla }_{\mathrm{KPC}}\end{array}$ \\
\hline TK-22 & E.coli & $>1$ & $\leq 0.25$ & 1 & $>64$ & Pozitif & Negatif & Negatif & - \\
\hline TK-23 & K.pneumoniae & $>1$ & $\leq 0.25$ & 1 & $>64$ & Pozitif & Negatif & Negatif & - \\
\hline TK-24 & E.coli & $\leq 0.25$ & $\leq 0.25$ & $\leq 0.125$ & 4 & Negatif & Negatif & Negatif & - \\
\hline TK-25 & K.pneumoniae & $>1$ & $\leq 0.25$ & 1 & $>64$ & Pozitif & Negatif & Negatif & - \\
\hline TK-26 & K.pneumoniae & $\leq 0.25$ & 0.5 & $\leq 0.125$ & $>64$ & Pozitif & Negatif & Negatif & - \\
\hline TK-27 & E.coli & $\leq 0.25$ & $\leq 0.25$ & $\leq 0.125$ & 32 & Negatif & Negatif & Negatif & - \\
\hline TK-28 & K.pneumoniae & $\leq 0.25$ & 0.5 & $\leq 0.125$ & $>64$ & Negatif & Negatif & Negatif & - \\
\hline TK-29 & K.pneumoniae & $\leq 0.25$ & $\leq 0.25$ & $\leq 0.125$ & 8 & Pozitif & Negatif & Negatif & - \\
\hline TK-30 & K.pneumoniae & $>1$ & 0.5 & 1 & $>64$ & Pozitif & Negatif & Negatif & - \\
\hline TK-31 & K.pneumoniae & $\leq 0.25$ & 1 & $\leq 0.125$ & 16 & Negatif & Negatif & Negatif & - \\
\hline TK-32 & K.aerogenes & $>1$ & 4 & 8 & 32 & Negatif & Negatif & Pozitif & $\begin{array}{c}b_{\mathrm{OXA}-48} \\
\text { la }_{\mathrm{NDM}}\end{array}$ \\
\hline TK-33 & E.cloacae & $>1$ & 8 & 2 & $>64$ & Negatif & Pozitif & Pozitif & $b / a_{\mathrm{VIM}}$ \\
\hline
\end{tabular}




\begin{tabular}{|c|c|c|c|c|c|c|c|c|c|}
\hline $\begin{array}{l}\text { İzolat } \\
\text { no }\end{array}$ & Bakteri türü & $\begin{array}{c}\text { ERT } \\
(\mu \mathrm{g} / \mathrm{ml})\end{array}$ & $\begin{array}{c}\text { iMP } \\
(\mu \mathrm{g} / \mathrm{ml})\end{array}$ & $\begin{array}{c}\text { MEM } \\
(\mu \mathrm{g} / \mathrm{ml})\end{array}$ & $\begin{array}{c}\mathrm{CO} \\
(\mu \mathrm{g} / \mathrm{ml})\end{array}$ & GSBL & AMP-C & CIM & $\begin{array}{l}\text { Direnç } \\
\text { genleri }\end{array}$ \\
\hline TK-34 & E.coli & $\leq 0.25$ & $\leq 0.25$ & $\leq 0.125$ & 16 & Negatif & Negatif & Negatif & $m c r-1$ \\
\hline TK-35 & E.coli & $\leq 0.25$ & $\leq 0.25$ & $\leq 0.125$ & 16 & Pozitif & Negatif & Negatif & - \\
\hline TK-36 & K.pneumoniae & $>1$ & 0.5 & 2 & $>64$ & Pozitif & Negatif & Negatif & - \\
\hline TK-37 & E.coli & $>1$ & 1 & 1 & 16 & Pozitif & Negatif & Pozitif & $\begin{array}{c}b_{\mathrm{OXA}-48} \\
\text { la }_{\mathrm{NDM}}\end{array}$ \\
\hline TK-38 & E.coli & $\leq 0.25$ & $\leq 0.25$ & $\leq 0.125$ & 32 & Pozitif & Negatif & Negatif & - \\
\hline TK-39 & K.aerogenes & $>1$ & 8 & 4 & 8 & Negatif & Pozitif & Negatif & - \\
\hline TK-40 & K.pneumoniae & $\leq 0.25$ & 0.5 & $\leq 0.125$ & 8 & Pozitif & Negatif & Negatif & - \\
\hline
\end{tabular}

mcr-1 pozitif PCR ürünü dizi analizinde 309 bp uzunluğunda veri elde edilmiştir. Dizi Blast veri tabanında araştırıldığında mcr-1 dizileri ile \%100 benzerlik görülmüştür.

Tespit edilen mcr-1 genleri hastanemizde tedavi gören 65 yaş üstü 2 kadın hastanın idrar kültürü örneklerinde üreyen E.coli izolatlarında bulunmuştur. Bu hastalardan 1'inde test edilen antibiyotikler arasında sadece ampisiline karşı direnç gözlenmiş, diğerinde ise sadece ampisilin, amoksisilin-klavulonik asit ve siprofloksasine karşı direnç belirlenmiştir.

\section{TARTIŞMA}

Enterobacterales ailesi üyeleri hem sağlık hizmeti ile ilişkili hem de toplum kaynaklı enfeksiyonların en önemli nedenleri arasındadır ${ }^{17}$. Hastanelerde her klinikte görülse de, enfeksiyonlarına en sık yoğun bakım ünitelerinde karşılaşılmakta ve sonuçları da daha ağır seyredebilmektedir ${ }^{18}$. Çalışmamıza dahil ettiğimiz kolistine dirençli Enterobacterales izolatları da en sık olarak yoğun bakım ünitelerinden (\%42.5) saptanmıştır.

Mobil kolistin direnç genlerinin ortaya çıkması, kolistin direncinin oluşması ve yayılması ile ilgili verilerin yeniden gözden geçirilmesine neden olmuştur ${ }^{6}$. Çin'de $m c r-1$ 'in keşfinden sonra dünyanın çeşitli bölgelerinden $m c r$ genleri ile ilgili bildirimler yayımlanmıştır ${ }^{5}$. Bu bildirimlerde Enterobacterales ailesinde sıklıkla mcr-1 ve mcr-3 tespit edilmiştir, $m c r-2, m c r-4$ ve $m c r-5$ varlığı oldukça nadirdir ${ }^{6}$. Ülkemizde $m c r-1$ geni ilk kez Kürekçi ve

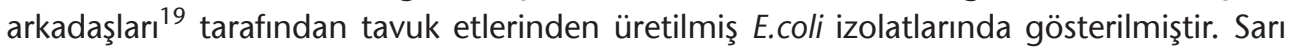
ve arkadaşları $^{20} 2017$ yılında yayımladıkları çalışmada toplam 22 merkeze ait 329 Enterobacterales izolatında $m c r-1$ ve $m c r-2$ gen varlığın PCR yöntemi ile araştırmış ancak çalışmaya alınan izolatların hiçbirinde aranan gen bölgelerine rastlanmamıştır. Arabacı ve arkadaşları $^{21} 2018$ yılında sundukları bildiride üç K.pneumoniae izolatında PCR yöntemi ile $m c r-1$ genini tespit ettiklerini bildirmişler ancak ileri doğrulama testlerini gerçekleştirememişlerdir. Kandemir ve arkadaşları ${ }^{22}$ Acinetobacter baumannii izolatında PCR yöntemi ile elde ettikleri amplifikasyon ürünlerini DNA dizi analizi ile incelediklerinde, hedeflenen 
bölge ile yaklaşık aynı bp uzunluğunda ancak \%60-80 oranlarında benzerlik tespit ettiklerini bildirmişler ve pozitif çıkan örneklerin DNA dizi analizi ile doğrulanmasının uygun olacağını önermişlerdir.

Bu çalışma, literatürde ulaşabildiğimiz kadarıyla ülkemizde klinik örneklerde mcr-1 geni varlığını gösteren ve DNA dizi analizi ile doğrulanmış ilk araştırmadır. Pozitif sonuçlardan birisi enfeksiyon hastalıkları polikliniğinde ayaktan takip edilen, diğeri ise iç hastalıkları nefroloji servisinde yatarak tedavi gören 65 yaş üstü iki kadın hastanın idrar kültürü örneklerinde etken olarak üreyen E.coli izolatlarında tespit edilmiştir. Ülkemizde tavuklardan izole edilen kolistine dirençli E.coli izolatlarının antibiyotik profilinde piperasiline, tetrasikline, levofloksasine, siprofloksasine, sefepime, aztreonama, seftazidime ve trimetoprimsülfametoksazole karşı direnç varlığı gösterilmiştir ${ }^{19}$. İzolatlarımızdan birinde test edilen antibiyotikler arasında kolistine, ampisiline, amoksisilin-klavulonik asite ve siprofloksasine karşı direnç gözlenmiş, diğerinde ise kolistin ve ampisilin dışında direnç belirlenmemiştir. Bu durum çoklu ilaç direnci görülmeyen izolatlarda da kolistin direncinin görülebileceğini hatırlatarak, tıbbi mikrobiyoloji laboratuvarlarında kolistin duyarlıık testi çalışılmasının önemini bir kez daha gözler önüne sermiştir.

Kolistine dirençli E.coli izolatlarında plazmit üzerinden $m c r-1$ geniyle birlikte GSBL ve kinolon direnç genlerinin de aktarılabildiğini gösteren çalışmalar mevcuttur ${ }^{2,3,19}$. Çalışmamızdaki izolatlar fenotipik testler ile GSBL negatif olarak tespit edilmiştir ancak izolatlarımızda konjugatif plazmit varlığı araştırılamaması çalışmamızın kısıtlı yanını oluşturmaktadır.

Karbapeneme dirençli bakterilerle gelişen enfeksiyonların tedavisinde tigesiklin, polimiksin, aminoglikozitler ve fosfomisin gibi antimikrobiyaller kullanılmaktadır; ancak bu moleküllerin farmakokinetik özellikleri, toksisiteleri ve gelişen direnç problemleri nedeniyle uygulanmasında kısıtıııklar yaşanmaktadır. Bu nedenle Enterobacterales ailesi üyelerinde gözlenen artan karbapenem direnci tüm dünyada ciddi kaygılar uyandırmaktadır ve gelişen direncin nedenlerini belirlemek giderek önem kazanmaktadır ${ }^{1,23}$. Bu nedenle çaıışmaya aldığımız kolistine dirençli bu özel grupta karbapenem direnci incelemeye değer bulunmuş ve yapılan incelemeler sonucunda izolatlarımızın 15 (\%37.5)'inde fenotipik olarak karbapenem direnci belirlenmiştir. Direnç nedenlerini incelediğimizde karbapenem inaktivasyon testinin pozitif bulunduğu dokuz izolatta direnç genlerinin (bla OXA-48' $_{\text {' }}$ $\left.b / a_{\mathrm{KPC}}, b l a_{\mathrm{NDM}^{\prime}} b / a_{\mathrm{VIM}}\right)$ varlığı tespit edilmiştir. Bu testin negatif bulunduğu altı izolatta direnç genlerine rastlanmış ancak iki izolatta $\mathrm{AmpC}$, dört izolatta GSBL üretimi görülmüş ve karbapenem direncinin bu enzimlerin aşırı üretimine bağlı olabileceği düşünülmüştür.

Ülkemizde yaygın olarak tespit edilen bla ${ }_{\mathrm{OXA}-48}$ geni bizim çalışmamızda da en sık rastlanan gen olmuştur ${ }^{24}$. Dünyada daha önce Monako, Tunus ve İsviçre'de gösterilmiş ve ülkemizde ilk kez 2015 yılında Kılıç ve arkadaşları ${ }^{25}$ tarafından K.pneumoniae izolatında bildirilmiş olan OXA-48 ve NDM birlikteliği daha sonra E.coli, Citrobacter freundii, Providencia rettgeri gibi farklı izolatlarda da gözlenmiştir ${ }^{26}$. Bizim çalışmamızda da beş izolatta $b / a_{\mathrm{OXA}-48}$ ve $b / a_{\mathrm{NDM}}$ gen varlığı beraber saptanmıştır. bla $a_{\mathrm{OXA}-48}$ ve $b / a_{\mathrm{NDM}}$ birlikte 
pozitif olan E.coli izolatında sadece ertapenem direncinin gösterilmiş olması, var olan direnç genlerinin aktif olmayabileceğini düşündürmüştür. Ancak konjugasyon çalışmaları ile doğrulanmamış olması çalışmamızın kısıtlı yanıdır.

NDM gibi diğer bir metallo-beta-laktamaz olan VIM ülkemizde 2014 yılında yapılan çok merkezli bir çalışmada \%2.8 oranında tespit edilmiştir ve pozitif saptanan dört izolattan biri merkezimizden gönderilmiştir ${ }^{27}$. Çalışmamızda da bla ${ }_{\mathrm{VIM}}$ geninin karbapenemaz ve AmpC beta-laktamaz üreten bir E.cloacae izolatında saptanmış olması, bölgemiz için var olan tehdidin hala devam ettiğini göstermektedir.

Ülkemizde ilk kez 2014 yılında Romanyalı bir hastanın endotrakeal aspirat kültüründe izole edilen K.pneumoniae izolatında $b / a_{\mathrm{KPC}}$ enzimi geni varlığı tespit edilmiş, ardından ülkemizin çeşitli bölgelerinden bildirimler yapılmıştır ${ }^{28}$. Literatürde ulaşabildiğimiz kadarıyla daha önce Tayvan ve İngiltere'de saptanan $b / a_{\mathrm{KPC}}$ ve bla $a_{\mathrm{OXA}-48}$ birlikteliğine ülkemizde çalışmamız dışında rastlanmamıştır 29,30 .

Sonuç olarak, çalışmamız literatürde ulaşabildiğimiz kadarıyla ülkemizde klinik örneklerde $m c r-1$ geni varlığını gösteren ve DNA dizi analizi ile doğrulanmış ilk çalışmadır. Çoklu ilaç direnci görülmeyen izolatlarda $\mathrm{mcr}$ geninin saptanmış olması tıbbi mikrobiyoloji laboratuvarlarında kolistin duyarlılık testi çalışılmasının önemini bir kez daha gözler önüne sermektedir. Ayrıca, çalışmamızda farklı direnç genlerini bir arada içeren izolatların saptanmış olması, karbapenem ve kolistin direncinin yayılımının beklenenden daha hızlı olabileceğini bir kez daha hatırlatmıştır. Kolistinin özellikle karbapeneme dirençli gramnegatif bakterilerin enfeksiyonlarının tedavisinde son seçenek olarak kullanılması, direnç yayılım mekanizmasının anlaşıımasının ve dirençli izolatlarla ilgili sürveyans çalışmalarının yürütülmesini oldukça önemli hale getirmiştir.

\section{ÇIKAR ÇATIŞMASI}

Yazarlar bu makale ile ilgili herhangi bir çıkar çatışması bildirmemişlerdir.

\section{KAYNAKLAR}

1. Liu YY, Wang Y, Walsh TR, Yi LX, Zhang R, Spencer J, et al. Emergence of plasmid-mediated colistin resistance mechanism $M C R-1$ in animals and human beings in China: a microbiological and molecular biological study. Lancet Infect Dis 2016; 16(2): 161-8.

2. Rhouma M, Beaudry F, Theriault W, Letellier A. Colistin in pig production: chemistry, mechanism of antibacterial action, microbial resistance emergence, and one health perspectives. Front Microbiol 2016; 7: 1789.

3. Poirel L, Kieffer N, Brink A, Coetze J, Jayol A, Nordmann P. Genetic features of mcr-1-producing colistin resistant Escherichia coli isolates in South Africa. Antimicrob Agents Chemother 2016; 60(7): $4394-7$.

4. Kawanishi M, Abo H, Ozawa M, Uchiyama M, Shirakawa T, Suzuki S, et al. Prevalence of colistin resistance gene $m c r-1$ and absence of $m c r-2$ in Escherichia coli isolated from healthy food-producing animals in Japan. Antimicrob Agents Chemother 2017; 61(1): e02057-16.

5. Xavier BB, Lammens C, Ruhal R, Kumar-Singh S, Butaye P, Goossens $H$, et al. Identification of a novel plasmid-mediated colistin resistance gene, $m c r-2$, in Escherichia coli, Belgium, June 2016. Euro Surveill 2016; 21(27): pii=30280. 
6. Wang X, Wang Y, Zhou Y, Li J, Yin W, Wang S, et al. Emergence of a novel mobile colistin resistance gene, $m c r-8$, in NDM-producing Klebsiella pneumoniae. Emerg Microbes Infect 2018; 7(1): 122.

7. European Committee on Antimicrobial Susceptibility Testing (EUCAST). Breakpoint tables for interpretation of MICs and zone diameters. Version 8.1, 2018.

8. EUCAST guidelines for detection of resistance mechanisms and specific resistances of clinical and/or epidemiological importance, Version 2.0, 2017.

9. Liu XQ, Liu YR. Detection and genotype analysis of AmpC $\beta$-lactamase in Klebsiella pneumoniae from tertiary hospitals. Exp Ther Med 2016; 12(1): 480-4.

10. Simona M, Gatermannb S, Pfeiferc Y, Reischla U, Gessnera A, Jantsch J. Evaluation of the automated BD Phoenix CPO Detect panel in combination with the $\beta$-CARBA assay for detection and classification of carbapenemase producing Enterobacterales. J Microbiol Methods 2019; 156: 29-33.

11. Robson RL, Essengue S, Reed NA, Horvat RT. Optochin resistance in Streptococcus pneumoniae induced by frozen storage in glycerol. Diagn Microbiol Infect Dis 2007; 58(2): 185-90.

12. Rebelo AR, Bortolaia V, Kjeldgaard JS, Pedersen SK, Leekitcharoenphon P, Hansen IM, et al. Multiplex PCR for detection of plasmid-mediated colistin resistance determinants, $m c r-1, \operatorname{mcr}-2, \operatorname{mcr}-3, \operatorname{mcr}-4$ and $m c r-5$ for surveillance purposes. Euro Surveill 2018; 23(6): 17-00672.

13. Borowiak M, Fischer J, Hammerl JA, Hendriksen RS, Szabo I, Malorny B. Identification of a novel transposonassociated phosphoethanolamine transferase gene, mcr-5, conferring colistin resistance in d-tartrate fermenting Salmonella enterica subsp. enterica serovar Paratyphi B. J Antimicrob Chemother 2017; 72(12): 3317-24.

14. Hindiyeh M, Smollen G, Grossman Z, Ram D, Davidson Y, Mileguir F, et al. Rapid detection of bla carbapenemase genes by real-time PCR. J Clin Microbiol 2008; 46(9): 2879-83.

15. Hofko M, Mischnik A, Kaase M, Zimmermann S, Dalpke AH. Detection of carbapenemases by real-time PCR and melt curve analysis on the BD Max system. J Clin Microbiol 2014; 52(5): 1701-4.

16. Avlami A, Bekris S, Ganteris G, Kraniotaki E, Malamou-Lada E, Orfanidou M, et al. Detection of metallo- $\beta$ lactamase genes in clinical specimens by a commercial multiplex PCR system. J Microbiol Methods 2010; 83(2): 185-7.

17. Paterson DL. Resistance in gram-negative bacteria: Enterobacteriaceae. Am J Infect Control 2006; 34(6 Suppl 1): S20-8.

18. Lai CC, Chen YS, Lee NY, Tang HJ, Lee SS, Lin CF, et al. Susceptibility rates of clinically important bacteria collected from intensive care units against colistin, carbapenems, and other comparative agents: results from Surveillance of Multicenter Antimicrobial Resistance in Taiwan (SMART). Infection and Drug Resistance 2019; 12: 627-40.

19. Kurekci C, Aydin M, Nalbantoglu OU, Gundogdu A. First report of Escherichia coli carrying the mobile colistin resistance gene mcr-1 in Turkey. J Glob Antimicrob Resist 2018; 15: 169-170.

20. Sarı AN, Süzük S, Karatuna $O$, Öğünç $D$, Karakoç $A E$, Çizmeci Z, et al. Results of a multicenter study investigating plasmid mediated colistin resistance genes ( $\mathrm{mcr}-1$ and $\mathrm{mcr}-2)$ in clinical Enterobacteriaceae isolates from Turkey. Mikrobiyol Bul 2017; 51(3): 299-303.

21. Arabacı Ç, Dal T, Başyiğit T, Genişel N, Durmaz R. Karbapenem dirençli Klebsiella pneumoniae izolatlarında karbapenem direnç mekanizmalarının değerlendirilmesi ve MCR-1 geninin araştırılması. 38. Uluslararası Türk Mikrobiyoloji Kongresi, 4-8 Kasım 2018, Antalya. Kongre Kitabı, s: 171-2, SS-084.

22. Kandemir T, Nağıyev T, Köksal F. Kolistin direncinin tespitinde yanlış tanı: yalancı MCR-1 pozitifliği. 38. Uluslararası Türk Mikrobiyoloji Kongresi, 4-8 Kasım 2018, Antalya. Kongre Kitabı, s: 190, SS-114.

23. Campos AC, Albiero J, Ecker AB, Kuroda CM, Meirelles LE, Polato A, et al. Outbreak of Klebsiella pneumoniae carbapenemase-producing K.pneumoniae: a systematic review. Am J Infect Control 2016; 44(11): 1374-80.

24. Tekintaş Y, Çilli F, Eraç B, Yaşar M, Aydemir SŞ, Hoşgör Limoncu M. Comparison of phenotypic methods and polymerase chain reaction for the detection of carbapenemase production in clinical Klebsiella pneumoniae isolates. Mikrobiyol Bul 2017; 51(3): 269-76. 
25. Kilic A, Baysallar M. The first Klebsiella pneumoniae isolate co-producing OXA-48 and NDM-1 in Turkey. Ann Lab Med 2015; 35(3): 382-3.

26. Otlu B, Yakupoğulları Y, Gürsoy NC, Duman Y, Bayındır Y, Tekerekoğlu MS, et al. Providencia rettgeri'de OXA48 ve NDM-1 karbapenemaz genlerinin birlikte üretimi: ilk bildirim. Mikrobiyol Bul 2018; 52(3): 300-7.

27. Çakar A, Akyön Y, Gür D, Karatuna O, Ögünç D, Özhak Baysan B, et al. Türkiye'de 2014 yılı içinde izole edilen karbapeneme dirençli Escherichia coli ve Klebsiella pneumoniae izolatlarında karbapenemaz varlığının araştırılması. Mikrobiyol Bul 2016; 50(1): 21-33.

28. Özyazıcı G, Özkaya E, Kaya H, Kocatürk Sel S, Altınbaşak H, Başarı F, et al. Investigation of bla $a_{\text {KPC }}$ gene by PCR in carbapenem-resistant Escherichia coli and Klebsiella pneumoniae clinical isolates in a tertiary care hospital in Turkey. Mediterr J Infect Microb Antimicrob 2019; 8: 3.

29. Chen CM, Guo MK, Ke SC, Lin YP, Li CR, Vy Nguyen HT, et al. Emergence and nosocomial spread of ST11 carbapenem-resistant co-producing OXA-48 and KPC-2 in a regional hospital in Taiwan. J Med Microbiol 2018; 67(7): 957-64.

30. Meunier D, Woodford N, Hopkins KL. Evaluation of the AusDiagnostics MT CRE EU assay for the detection of carbapenemase genes and transferable colistin resistance determinants $m c r-1 /-2$ in MDR gram-negative bacteria. J Antimicrob Chemother 2018; 73(12): 3355-8. 